\title{
Unusual presentation of an Adie-like pupil
}

\section{Cat's eye pupil}

Robert A. Egan, MD, and Carla Avruskin, OD

Neurology ${ }^{\circledR}$ 2018;91:715-716. doi:10.1212/WNL.0000000000006327

Correspondence

Dr. Egan

Eganr8@gmail.com

Figure 1 Close-up shows normal left pupil and tonic right cat's eye pupil

A 55-year-old woman noticed that her right pupil was oddly shaped, associated with a mild ache. Her afferent visual examination, ocular and eyelid motility, and fundi were normal. Her left pupil was round and reactive (figure 1). The right pupil was elongated (points at 11:00 and 5: 00 ) and tonic (figure 2). There was no ocular hypertension or corneal edema. A year later, the pupil shape became triangular; evaluation revealed ocular hypertension without corneal edema, confirming the iridocorneal endothelial (ICE) syndrome. This case is an unusual presentation of a cat's eye Adie-like pupil as the harbinger for ICE syndrome.

An Adie pupil is a benign tonic pupil typically associated with sectoral paralysis of the iris sphincter muscle. ICE syndrome is associated with iris atrophy, glaucoma, and corneal edema; here, there were 2 of the 3 findings. An unusual shape to an Adie-like pupil should suggest the ICE syndrome. Referral to an ophthalmic specialist is warranted.

\section{Author contributions}

R. Egan: data acquisition, study concept and design, analysis, interpretation of data, critical revision of manuscript for important intellectual content. C. Avruskin: data acquisition, study concept and design, critical revision of manuscript for important intellectual content.

\section{Study funding}

No targeted funding reported.

\section{Disclosure}

The authors report no disclosures relevant to the manuscript. Go to Neurology.org/ $\mathrm{N}$ for full disclosures. 
Figure 2 There was sectoral paralysis of the iris between 12:00 and 4:00 and also from 6:00 to 10:00 with mild thinning of the pupillary ruff on the temporal iris characteristic of an Adie-like pupil

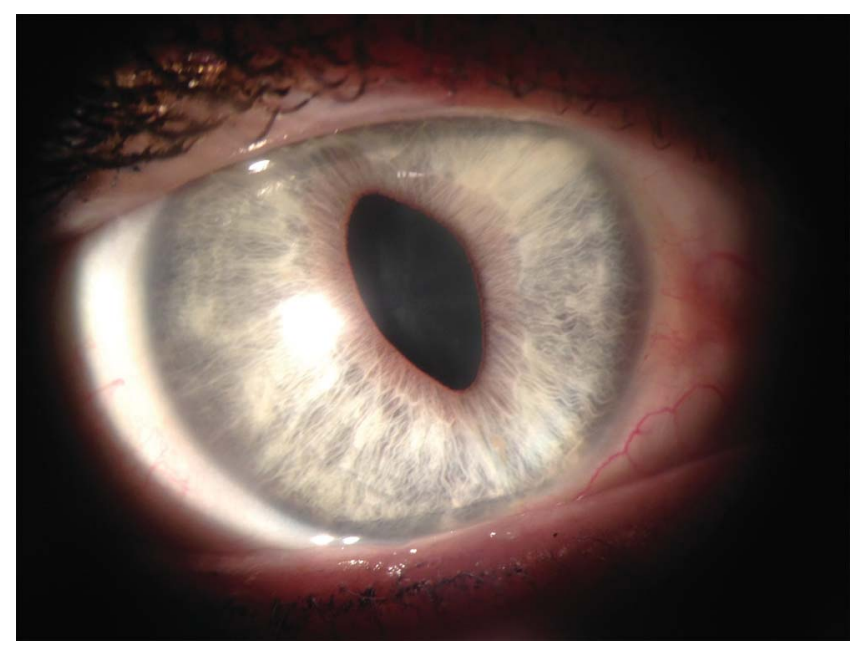

\section{Are You Ready to Maximize Your Medicare Reimbursement?}

Use the AAN tools and resources to earn positive payments and avoid penalties under MIPS.

Take action today, visit AAN.com/view/QPP

\section{Sign Up for the AAN's Axon Registry}

The AAN encourages its US members to show their interest in participating in the Axon Registry ${ }^{\circledR}$ by signing up today.

Use the Axon Registry to:

- Simplify reporting requirements under MACRA's Quality Payment Program and avoid penalties while reducing your administrative burden

- Meet your MOC Part IV requirements and waive up to eight credits of Part II Self-Assessment

- Choose from 22 AAN neurology-specific quality measures that fit your practice

- Use data to understand your practice and identify where improvements can be made to patient care

- Manage your patients at a population level; look at a specific group of patients based on conditions, risk factors, demographics or outcome

- Demonstrate your value to payers when negotiating reimbursement

- Enjoy multi-year, fee-free access when you sign the agreements and integrate your EHR with the registry

Learn more at AAN.com/view/Axon and send your questions to registry@aan.com. 


\section{Neurology}

\section{Unusual presentation of an Adie-like pupil: Cat's eye pupil \\ Robert A. Egan and Carla Avruskin \\ Neurology 2018;91;715-716 \\ DOI 10.1212/WNL.0000000000006327}

This information is current as of October 8, 2018

\section{Updated Information \& Services \\ Subspecialty Collections}

Permissions \& Licensing

Reprints including high resolution figures, can be found at: http://n.neurology.org/content/91/15/715.full

This article, along with others on similar topics, appears in the following collection(s):

All Clinical Neurology

http://n.neurology.org/cgi/collection/all_clinical_neurology

All Neuro-ophthalmology

http://n.neurology.org/cgi/collection/all_neuroophthalmology

Pupils

http://n.neurology.org/cgi/collection/pupils

Information about reproducing this article in parts (figures,tables) or in its entirety can be found online at:

http://www.neurology.org/about/about_the_journal\#permissions

Information about ordering reprints can be found online:

http://n.neurology.org/subscribers/advertise

Neurology ${ }^{\circledR}$ is the official journal of the American Academy of Neurology. Published continuously since 1951 , it is now a weekly with 48 issues per year. Copyright @ 2018 American Academy of Neurology. All rights reserved. Print ISSN: 0028-3878. Online ISSN: 1526-632X.

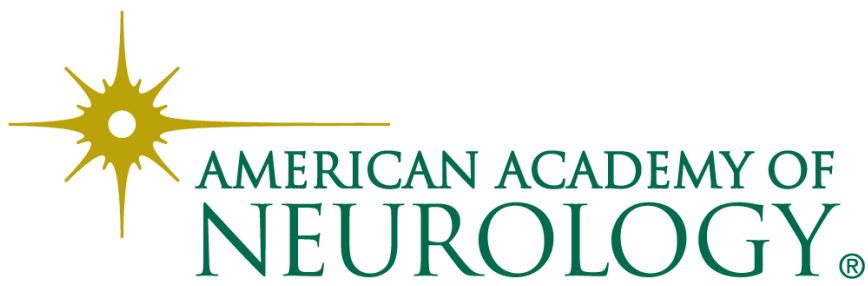

